\section{Impact of clinical and patient pathway changes on paediatric research during the national COVID-19 response}

In March 2020, in response to the COVID-19 pandemic, national strategies were implemented across Scotland to contain the spread of the virus, including lockdown measures, travel restrictions and the closure of schools and non-essential services. The National Institute for Health Research (NIHR) and the devolved nations prioritised nationally sponsored COVID-19 research and front-line care. ${ }^{1}$ As a result, $78 \%$ of paediatric studies in Scotland were suspended.

In August 2020 after the first COVID-19 wave, the RESTART programme was initiated across health boards to reopen commercial and non-commercial research studies. By March 2021, most paediatric studies were categorised as open to recruitment but without the expected resurgence of patient recruitment. We therefore surveyed the principal investigators (PI) about their opinions on factors, specifically those related to the national COVID-19 strategies, that were affecting recruitment to their paediatric studies.

A survey of 11 questions, designed using the SNAP Survey software and hosted on a secure University of Aberdeen server, was sent to the 105 PIs listed in the national database (Scottish Research Management Database) under the paediatric portfolio. The survey was open from 16 March to 16 April 2021.

The 72 responses received were proportionate to the National Health ServiceNational Research Services Children's Research Network portfolio categorisation by health board, specialty, study type and whether studies are embedded in clinical care (table 1).

The survey highlighted factors within the clinical environment that were considered to have a negative impact on recruitment and follow-up visits (table 2):

1. Availability Reduced availability of staff was reported most frequently, exacerbated by staff redeployment to COVID-19-related adult research and vaccine studies.

2. Frequency Factors that collectively reduced the frequency of interactions with potential study participants and

Table 1 Breakdown of 72 responses to survey of paediatric principal investigators in Scotland

\begin{tabular}{ll}
\hline $\begin{array}{l}\text { Breakdown of } \\
\text { responses }\end{array}$ & \\
\hline Health board & $\begin{array}{l}\text { NHS Greater Glasgow and Clyde 28, NHS Lothian 18, NHS Grampian 12, NHS Tayside 10, NHS } \\
\text { Ayrshire and Arran 2, NHS Lanarkshire 1, NHS Fife 1 }\end{array}$ \\
Specialty & $\begin{array}{l}\text { Neurology } 17(24 \%), \text { Respiratory 13 (18\%), Gastroenterology } 6(8 \%), \text { Neonatology } 4(6 \%), \\
\text { Anaesthesia } 4(6 \%), \text { Surgery } 4(6 \%), \text { Rheumatology } 4(6 \%), \text { Infectious diseases } 2(4 \%), \text { Intensive } \\
\text { medicine 3 (4\%), Dermatology 2 (3\%), Endocrinology } 2(3 \%), \text { Other } 4(6 \%)\end{array}$ \\
Study type & $\begin{array}{l}50 \% \text { Clinical Trials of an Investigational Medicinal Product (CTIMPs), 24\% interventional trials } \\
\text { not involving an IMP (non-CTIMP), 20\% observational studies, 6\% registries } \\
63 \% \text { considered their study to be embedded in clinical care. }\end{array}$ \\
\hline
\end{tabular}

NHS, National Health Service.

Table 2 The total number and percentage of Yes responses to 'Has recruitment been affected by changes to the clinical pathway in your specialty?' and 'Have follow-up visits been affected by changes to the clinical pathway in your specialty?'

\begin{tabular}{lll}
\hline & $\begin{array}{l}\text { Has recruitment been } \\
\text { affected by changes to } \\
\text { the clinical pathway in } \\
\text { your specialty? Please } \\
\text { select all that apply. }\end{array}$ & $\begin{array}{l}\text { clinical pathway in your } \\
\text { specialty? Please select all } \\
\text { that apply. }\end{array}$ \\
\hline Categories & $14(22.6 \%)$ & $16(30.2 \%)$ \\
\hline $\begin{array}{l}\text { Patients not attending routine clinics } \\
\text { Patients not attending face-to-face appointments }\end{array}$ & $16(25.8 \%)$ & $21(39.6 \%)$ \\
$\begin{array}{l}\text { Patients/parents not keen to attend face-to-face } \\
\text { appointments }\end{array}$ & $11(17.7 \%)$ & $11(20.8 \%)$ \\
$\begin{array}{l}\text { Elective procedures suspended } \\
\text { Supportive procedures not available-for example, } \\
\text { radiology, cardiology, ophthalmology }\end{array}$ & $13(21.0 \%)$ & $7(13.2 \%)$ \\
$\begin{array}{l}\text { Staff to support research not available due to staff } \\
\text { redeployment or shortages }\end{array}$ & $21(33.9 \%)$ & $3(5.7 \%)$ \\
$\begin{array}{l}\text { You have less time due to clinical pressure } \\
\begin{array}{l}\text { Less opportunity to recruit patients due to social } \\
\text { distancing requirements }\end{array}\end{array}$ & $15(24.2 \%)$ & $7(13.2 \%)$ \\
\hline
\end{tabular}

their families, including reduced clinics, travel restrictions between health board areas, reduced willingness to invite patients to hospital and postponement of elective procedures.

3. Quality Factors that impacted on the quality of interactions with patients and families, including the replacement of face-to-face visits by telephone or video calls, socially distanced visits with less family members present and wearing of face masks.

Furthermore, changes in the incidence of some conditions were considered to have affected recruitment to specific studies including a significant reduction in seasonal respiratory infections, and in fractures presenting to emergency departments, explained by lockdown and suspension of sports and school activities.

In conclusion, the national and local NHS strategies implemented to reduce the spread of COVID-19 have collectively had a significantly negative impact on recruitment of children to research studies in Scotland. Through consultation with the NIHR Clinical Research Network: Children and Young People National Specialty Group, these findings reflect the issues faced in paediatric research in England, Northern Ireland and Wales.

We envisage that the increased frequency and quality of clinical visits in conjunction with the NIHR National Managed Recovery process should lead to paediatric research activity returning to prepandemic levels. We believe that the reinstatement of clinical services and unrestricted movement of research staff within the clinical areas will particularly benefit studies with opportunistic patient recruitment.

\section{Pamela Dicks $\odot,{ }^{1}$ Jürgen Schwarze $\odot, 2$ Paul Dimitri ${ }^{3}$}

${ }^{1}$ Children's Research Network, Royal Aberdeen Children's Hospital, NHS Scotland, Aberdeen, UK ${ }^{2}$ Children's Research Network and Department of Child Life and Health, Centre for Inflammation Research, The University of Edinburgh, Edinburgh, UK

${ }^{3}$ NIHR Children and Young People MedTech Cooperative, Sheffield Children's Hospital NHS Foundation Trust, Sheffield, UK 
Correspondence to Dr Pamela Dicks, Children's

Research Network, NHS Scotland, Aberdeen AB25 2ZG, UK; pamela.dicks@nhs.scot

Twitter Pamela Dicks @Pamela Dicks@dicks_pamela

Contributors The design, distribution and analysis of the survey were conducted by PDic and JS. The letter was written by PDic, JS and PDim.

Funding This research was supported by the Chief Scientist Office Scotland NHS-NRS Children's Research Network and the National Institute for Health Research (NIHR) CRN: Children and Young People.

Disclaimer The views expressed are those of the authors and not necessarily those of the NHS, the CSO, NIHR or the Department of Health.

Competing interests None declared.

Patient consent for publication Not required.

Provenance and peer review Not commissioned; internally peer reviewed.

\section{(2) \\ OPEN ACCESS}

Open access This is an open access article distributed in accordance with the Creative Commons Attribution Non Commercial (CC BY-NC 4.0) license, which permits others to distribute, remix, adapt, build upon this work non-commercially, and license their derivative works on different terms, provided the original work is properly cited, appropriate credit is given, any changes made indicated, and the use is non-commercial. See: http:// creativecommons.org/licenses/by-nc/4.0/.

(C) Author(s) (or their employer(s)) 2021. Re-use permitted under CC BY-NC. No commercial re-use. See rights and permissions. Published by BMJ.

D) Check for updates
To cite Dicks P, Schwarze J, Dimitri P. Arch Dis Child 2021;106:e50.

Accepted 28 July 2021

Published Online First 24 August 2021

Arch Dis Child 2021;106:e50. doi:10.1136/archdischild-2021-322865

\section{ORCID iDs}

Pamela Dicks http://orcid.org/0000-0002-1696-0757 Jürgen Schwarze http://orcid.org/0000-0002-6899$748 \mathrm{X}$

Paul Dimitri http://orcid.org/0000-0001-7625-6713

\section{REFERENCE}

1 DHSC issues guidance on the impact of COVID-19 on research funded or supported by NIHR. Available: https://www.nihr.ac.uk/news/dhsc-issues-guidanceon-the-impact-of-covid-19-on-research-funded-orsupported-by-nihr/24469 [Accessed 16 Mar 2020]. 